Biol Neonate 1993;63:I-V

\title{
Contents, Vol. 63, 1993
}

\section{No. 1}

No. 2

Original Paper

B and T Lymphocyte Subsets in Fetal and Cord 1

Blood: Age-Related Modulation of CDlc Expression

Plebani, A.; Proserpio, A.R.; Guarneri, D.; Buscaglia, M.; Cattoretti, G.

Urinary Growth Hormone Excretion in Preterm 8

Neonates

Tsukahara, H.; Fujii, Y.; Kuriyama, M.; Tsuchida, S.;

Hiraoka, ML; Kikuchi, K.; Sudo, M.

Respiratory Distress Syndrome in Copper Defí- 14 ciency: An Experimental Model Developed in Rats

Sarricolea, M.L.; Villa-Elizaga, I.; Lopez, J.

Differential Expression of c-erbA mRNAs in the 26 Developing Cerebellum and Cerebral Cortex of the Rat Sherer, T.T.; Sylvester, S.R.; Bull, R.J.

In vitro Binding of [3H]Bilirubin to Neurons in 35 Rat Brain Sections

Danbolt, N.C.; Hansen, T.W.R.; Øyasæter, S.; Storm-Mathisen, J.; Bratlid, D.

Effect of Acute Maternal Alcohol Consumption 40 on the Fetal Ductus arteriosus in the Rat

Arishima, K.; Yamamoto, M.; Takizawa, T.; Sohmiya, H.; Eguchi, Y.; Shiota, K.

Ornithine Decarboxylase Activity and Urea in

Liver of Late-Pregnant Rats. Effect of Streptozotocin-Induced Diabetes Poveda, B.; Soler, C;

Soley, M.; Pastor-Anglada, M.

Secretin Induces Precocious Cessation of Intesti- 52 nal Macromolecular Transmission and Maltase Development in the Suckling Rat Harada, E.; Syuto, B.

Brief Communication

Osteocalcin and Human Milk 61

Pittard, III, W.B.; Geddis, K.M.; Hollis, B.W.

Acknowledgement 64

Original Paper

Leukotriene B4 and C4 Generation by Human

65

Colostral Macrophages in vitro Shimizu, T.; Niklasson, A.; Strandvik, B.

Elevated Venous Concentrations of Vasoactive 70 Intestinal Polypeptide in Cord Blood of Infants with Fetal Distress

Ishitani, N.; Ohzeki, T.; Hanaki, K.; Motozumi, H.; Sunaguchi, M.; Shiraki, K.

Use of Preestablished Criteria for Deciding on

75

Extubation in the Very Low Birthweight Newborn. Preliminary Analysis of a Randomized Study Huon, D.; Moriette, G; Mussat, P.; Parat, S.; Relier, J.P.

Flavin Adenine Dinucleotide Levels in Erythro- 80 cytes of Very Low Birthweight Infants under Vitamin Supplementation Becker, K.; Wilkinson A.R. 
Comparative Disposition Kinetics of[ ' 'In- 86

Labeled Group B Streptococcus and Neutrophils

during Onset of Sepsis-Induced Pulmonary

Hypertension

Aziz, S.M.; Sandefer, E.P.; Pauly, T.H.; Gillespie, M.N.

Surfactant Improves Lung Function and Mor- $\quad 96$

phology in Newborn Rabbits with Meconium

Aspiration

Sun, B.; Curstedt, T.; Song, G.-W.; Robertson, B.

Metabolism of Phospholipids in Rat Kidney 105

during Development Kahane, V.L.; Sterin-Speziale, N.

Glycogen Phosphorylase: Developmental Expres- 113

sion in Rat Liver

Bloch, C.A.; Ozbun, M.A.; Khan, S.A.

Cerebral Blood Flow Measurements in the New- 120 born Dog

Koons, A.H.; Wurtzel, D.; Metcalf, J.M.; Fellus, J.; Vannucci, R.; Hiatt, M.; Hegyi, T.

Brief Communication

Fetal $\mathrm{pH}$ Improvement after $24 \mathrm{~h}$ of Severe, 129

Nonlethal Hypoxia

Wikening, R.B.; Boyle, D.W.; Meschia, G

III

No. 3

No. 4

Editorial

Bilirubin Metabolism in the Newborn

Rubaltelli, F.F.

Original Paper

Sighs and Their Relationship to Apnea in the

Newborn Infant

Alvarez, J.E.; Bodani, J.; Fajardo, C.A.;

Kwiatkowski, K.; Cates, D.B.; Rigatto, H.

Cord Blood Erythropoietin, $\mathrm{pH}, \mathrm{PaC}^{1} / 8$ and Hae- 147

matocrit following Caesarean Section before

Labour

Rollins, M.D.; Maxwell, A.P.; Afrasiabi, M.;

Halliday, H.L.; Lappin, T.R.J.

When Is the Fetus First Capable of Gastric Acid, 153 Intrinsic Factor and Gastrin Secretion?

Kelly, E.J.;Brownlee, K.G.

Reduced Secretion of Interleukin-1 and Tumor 157 Necrosis Factor- $\alpha$ by Neonatal Monocytes

Peters, A.M.J.; Bertram, P.; Gahr, M.; Speer, C.P.

Separate and Conjugated in vitro Effects of Clofi- 163 brate and of an Organic Extract of Rat Amniotic Fluid on Microperoxisomes of Fetal Mouse Small Intestine Calvert, R.; Dauça, M.

Endotoxemia and Brain Bilirubin in the Rat 171

Hansen, T.W.R.; Maynard, E.C.; Cashore, W.J.; Oh, W. 
Reproductive Abnormalities in the Prepubertal 177 Jaundiced Gunn Rat Saiduddin, S.; Davis, D.R.

Protection by L-Ascorbic Acid against Photo183

toxicity in Tin-Protoporphyrin-Treated

Suckling Rats

Keino, H.; Mimura, S.; Nagae, H.; Banno, T.;

Kashiwamata, S.

Postnatal Changes in Selected Bacterial Groups 191 of the Pig Colonic Micro flora Swords,

W.E.; Wu, C.-C; Champlin, F.R.; Buddington, R.K.

Original Paper

Displacement of Bilirubin from Albumin by 201

Berberine

Chan, E.

Effect of Skinfold Thickness on Transcutaneous 209 Bilirubin Measurements Amit, Y.; Jabbour,

S.; Arad, I.D.

Effects of Birth weight Status and Gestational Age 215

on the Quality of General Movements in Preterm

Newborns

Geerdink, J.J.; Hopkins, B.

Prevalence and Toxigenicity of Clostridium diffi- 225 cue Isolates in Fecal Microflora of

Preterm Infants in the Intensive Care Nursery El-Mohandes, A.E.; Keiser, J.F.; Refat, M.;

Jackson, B.J.

Low-Density Lipoprotein Catabolism does not 230 Respond to Estrogen in the Fetal and

Newborn Rat

Plonné, D.; Winkler, L.; Schröter, A.; Dargel, R.

Influence of the Destabilisation of the Maternal 236

Digestive Microflora on That of the Newborn

Rat

Brunei, A.; Gouet, Ph.

Effect of Exogenously Administered Polyamine 246 on the Structural Maturation and Enzyme

Ontogeny of the Postnatal Rat Intestine Wild, G.E.; Daly, A.S.; Sauriol, N.; Bennett, G.

Perinatal Development of Brunner's Glands in 258 the Rat: Morphometrical Study Morikawa, Y.; Miyamoto, M.; Okada, T.

Developmental Changes in the Erythrocyte 268

Metabolism in Bandicoot Isoodon macrourus Agar, N.S.; Gemmell, R.T.

IV

Contents

No. 5

No. 6

Original Paper

Placental Transfer of Free Fatty Acids:

Importance of Fetal Albumin Concentration and Acid-Base Status Stephenson, T.; Stammers, J.; Hull, D.

Soluble Interleukin-2 Receptor and Interleukin-2 281 
in Human Amniotic Fluid of Normal and

Abnormal Pregnancies

Shohat, B.; Shohat, M; Faktor, J.H.; Barkay, G.;

Harell, D.; Kozenitzky, L.; Shohat, M.

Cobalt-Mesoporphyrin Inhibits Heme Oxygenase 285

Activity but It Does Not Induce Lipid Peroxida-

tion in Rat Brain Membranes during Photoirra-

diation

Keino, H.; Banno, T.; Mimura, S.; Kashiwamata, S.

Acute Effects of Cocaine on Ornithine Decarbox- 290 ylase Activity in Fetal and Neonatal Rat

Heart: Evidence of Cardiotoxicity Slotkin, T.A.; Johnson, D.J.; Seidler, F.J.

Lipoxygenase Activity in Rat Embryos and Its 297 Potential for Xenobiotic Oxidation Roy, S.K.;

Mitra, A.K.; Hilbelink, D.R.; Dwornik, J.J.; Kulkarni, A.P.

Effects of Epidermal Growth Factor on Orni- 303

thine Decarboxylase Activity and DNA Synthesis in Rats during the Perinatal Period Yamamoto, D.; Hiramatsu, Y.; Eguchi, K.; Kudo, T.

Stimulatory Effects of Insulin on DNA Synthesis 310 in Suckling Mouse Colon Ménard, D.;

Dagenais, $\mathrm{P}$.

Falling Intracranial Pressure: An Important Ele- 316 ment in the Genesis of Intracranial

Hemorrhage in the Beagle Puppy Coulter, D.M.; Gooch, W.M.

Breast Feeding and Formula Feeding Affect Dif- 327 ferently Plasma Thyroid Hormone

Concentrations in Infant Baboons Lewis, D.S.; McMahan, C.A.; Mott, G.E.

Brief Communication

Reduced Levels of Alpha-1 -Antitrypsin in Chil- 336 dren Exposed to High Levels of Air

Pollution

Dziegielewska, K.M.; Guminska, M.; Matthews, N.; Saunders, N.R.; Wilkinson, G.

Announcement $\quad 340$

Erratum $\quad 340$

Original Paper

Analysis of Risk Factors Influencing Imminent 341 Distress in Growth-Retarded Fetuses

Undergoing Oxygen Test

Arduini, D.; Rizzo, G.; Gioele Garzetti, G.; Romanini, C.

Erythromycin Increases Gastric Antral Motility 349 in Human Premature Infants Tomomasa, T.;

Miyazaki, M.; Koizumi, T.; Kuroume, T.

Effects of Diets with Different Content in Pro- 353 tein and Fiber on Embryotoxicity Induced by

Experimental Diabetes in Rats Giavini, E.; Airoldi, L.; Broccia, M.L.; Roversi, G.D.; Prati, M.

Effects of Hyperbaric Oxygen on Rat Embryos 360 Sapunar, D.; Saraga-Babic, M.; Peruzovic,

M.; Marusvic, M.

Age-Related Changes in Endotoxin Sensitivity 370 and the Febrile Response of Newborn

Rabbits Hull, D.; Mclntyre, J.; Vinter, J.

Effects of Hypoxia on Phrenic Neurogram 380

Response to Vagal and Somatic Stimulation in Newborn Rabbits Trippenbach, T.

Endothelium-Dependent Relaxation and the 389

Acute Pulmonary Vascular Response to Alveolar Hyperoxia in Neonatal Pigs Day, R.W.;

Klitzner, T.S.; Ignarro, L.J.

Case Report 
Faint-Positive Amniotic Fluid Acetylcholinester- 397 ase in a Case of Sacrococcygeal Teratoma Dupont, M.; Boulot, P.

Author Index 399

Subject Index 401 